TAD, C.40/S.69, 2021, s.28-54

\title{
SURIYE'DE KULLANILAN ÖNEMLİ TICARÎ, DİNî VE ASKERÎ YOL GÜZERGÂHLARI VE BU YOLLARIN KONTROLÜ MESELESİ (IX-XI.YY)
}

\author{
IMPORTANT COMMERCIAL, RELIGIOUS AND \\ MILITARY ROAD ROUTES USED IN SYRIA AND THE \\ CONTROL OF THESE ROADS (9TH-11TH C.)
}

\section{Sedat BILIINIR*}

\author{
Makale Bilgisi \\ Başvuru: 31.05 .2020 \\ Kabul: 05.10.2020
}

\author{
Article Info \\ Received: May 31, 2020 \\ Accepted: October 05, 2020
}

\begin{abstract}
Özet
Ortaçă̆'da, ticari yolların geçtiği güzergâhlara hâkim olmanın avantajları olduğu kadar dezavantajları da vardı. Ortaçă̆'da Suriye bu özelliğe sahip bir ülkeydi. Anadolu ile Orta Doğu arasında köprü vazifesi gördüğü için oldukça işlek yollara sahipti. Ayrıca denize kıyısı olması ve Hac yolu güzergâhının bu ülkeden geçmesi, önemini arttıran bir diğer etkendi. Bu sebeplerden dolayı bölgede sürekli bir hâkimiyet mücadelesi söz konusuydu. Bu coğrafya, kendisine hâkim olana büyük bir ekonomik güç kazandırsa da bunun yanında da çok fazla düşman kazandırıyordu. Bu bağlamda çalışmada, bölgeye hâkim olan güçlerin bu ülkede en çok kullandıkları yollar ve tercih ettikleri güzergâhlar ana kaynaklar ışığında belirlenmeye çalışıldı. Ticarî, dinî ve askerî açıdan en çok tercih edilen yollar, bu yolların avantajları ve dezavantajları, dönem dönem farklılıklar arz etmekteydi. Hükümdarlar, dönemin koşullarına göre kendince önlemler alıp bu sistemin bozulmaması için ellerinden gelen gayreti azamî derecede kullanmaya özen gösteriyorlard. Bu yollarda hükümdarlar için olmazsa olmaz niteliğe sahip olan bir diğer mesele de iletişimi sağlamaktı. Bunlara ek olarak, karayoluna klyasla denizyolu taşımacılı̆̆ı da oldukça ciddi boyutlara ulaşmıştı. Denizyolu taşımacılı̆̆ının neden tercih edildiği, ikisinin de tüccarlar açısından avantajları ve dezavantajları, kroniklerin, seyyahların gözlemleri doğrultusunda verilen bilgiler ışı̆̆ında anlatılmaya çalışılmıştır.
\end{abstract}

Anahtar Kelimeler: Suriye, Hac Yollarl, Ticari yollar, Denizyolu, Karayolu

\footnotetext{
* Dr. Öğr. Üyesi, Hatay Mustafa Kemal Üniversitesi, Fen-Edebiyat Fakültesi, Tarih Bölümü, ORCID: https://orcid.org/0000-0002-2327-9038, sedatbilinir@hotmail.com.
} 


\begin{abstract}
In the Middle Ages, there were disadvantages as well as advantages of dominating the routes through which commercial roads passed. Syria was a country with this feature in the Middle Ages. As it served as a bridge between Anatolia and the Middle East, it had very busy roads. In addition, the fact that it is on the coast and the pilgrimage route passes through this country was another factor that increased its importance. For these reasons, there was a constant struggle for sovereignty in the region. Although this geography gained a great economic power to the dominant its, it also brought many enemies. In this context, in this study, it is tried to determine the paths and routes preferred by the dominant forces in this country in the light of main sources. The most preferred commercial, religious and military routes, the advantages and disadvantages of these roads varied from time to time. According to the conditions of the time, the rulers took the utmost care to take their own measures and make maximum use of their efforts in order not to break this system. In these ways, another factor that was essential for the sovereigns was to provide communication. In addition, maritime transport compared to the road had also reached considerable levels. It is tried to explain why maritime transportation is preferred, advantages and disadvantages of both in terms of merchants, in the light of the information given in the observations of chronicles and travelers.
\end{abstract}

Keywords: Syria, Pilgrimage Roads, Commercial roads, Seaway, Highway

\title{
Giriş
}

Ortaçağ'da ekonomik olarak güçlü bir yapıya ulaşmak için gerekli koşulların en önemlilerinin başında ticaret yollarının kontrolünü elinde bulundurmak geliyordu. Çünkü ticari yollar ciddi bir vergi geliriydi. Taşımacılık ve ticaret ekonominin çok önemli bir ayağını oluşturmaktaydı. Taşımacılığın gerilemesi ya da önlenmesi, endüstri ve tarımı büyük oranda sekteye uğratırdı. Ortaçağ Müslüman coğrafyası da bu durumun öneminin farkındaydı. Dönemin Müslüman coğrafyacıları bu konu üzerinde durmuş ve önemli bilgiler vermişlerdir. Makdisi, Hurdazbih, İbn Havkal, Nasr-1 Hüsrev, Ebu'l Fidâ, bunlara örnek olarak gösterilebilir ${ }^{11}$. Bu coğrafyacılar genellikle iki şehir arasındaki mesafeyi, önemli şehirlerin çevre şehirlere olan uzaklıklarını, yolun durumu, gibi bilgileri eserlerinde vererek bu amaç doğrultusunda önemli bir hizmette bulunmuşlardır. $\mathrm{Bu}$ yolların bazıları Müslümanlar ve Hıristiyanlar için önemli olan Hac yolları ile kesiştiği zaman önemi çok daha ciddi boyutlara ulaşmaktaydı. Durum böyle olunca bu yolların

\footnotetext{
1 Ortaçağ kroniklerinin belirtmiş olduğu şehirler ya isim değişikliğine uğramış ya da günümüzde bulunmamaktadır. Bu şehirleri tespit ettiğimiz kadarıyla belirtmeye çalıştık.
} 
kontrolünü elde tutmak en az bu yolları ele geçirmek kadar zor bir hal alıyordu.

Ortaçağ' da Şam bölgesine ulaşımı sağlayan birbirine paralel dört güzergâh bulunmaktaydı. Bunlar; Kıyı ovaları (İskenderun'dan Gazze'nin güneyine kadar uzanır), Dağların uzandığı güzergâhlar, Asi Nehri'nin düzlükleri, Tepeler ve dağlık yollar. X. ve XI. Yüzyıllarda Suriye'deki en önemli yollar ülkenin coğrafi yapısına paralel olarak uzanan yollardı. Bölgedeki ana yollar ilçelerin başkentlerini birbirine bağliyordu. Bu yol kuzeyde Halep'ten başlayıp Humus, Şam, Tiberias'a (Tiberya) kadar gelip güneyde Remle'ye (Ramla) kadar uzanmaktaydı. Mısır'a ulaşmak için dağlar ve ovalar geçmek gerekliydi. Bu ana karayolu Humus'ta ikiye ayriliyor ve Şam'da yeniden birleşiyordu. Batı kolu Humus'tan başlayıp Asi Nehri boyunca devam ediyor ve Baalabek'e kadar uzanıyordu. Daha sonra Şam'a kadar Barada Nehrine paralel ilerliyordu. Doğu yolu ise daha çok çöl yoluydu, Humus'tan başlayıp Qarah, al-Nabq (Al Nabk), al-Qutayyifah'a (Al Qutayfah) geçiyor ve Şam'a ulaşıyordu. Bu yol ülkeyi kuzey-güney yönlü olarak geçmekteydi. (Bkz. Ek.1).

Sahil yolu da Antakya'dan başlar Lazkiye, Tripoli (Trablus), Beirut, Tyre (Sur), Acre (Akka), Cesaren, Jaffa (Yafa), Asqalan (Aşkelon-Ashqelon) ve en son Gazze'nin güneyine kadar devam etmekteydi².(Bkz. Ek.2). Ebu'l Fida Şam bölgesine geldiğinde burayı 9 bölgeye ayırmıştı. Her bölge için, cetvel, adını kullanmıştı. Her cetvelde bulunan şehir isimlerini de tek tek yazmıştır ${ }^{3}$. $\mathrm{Bu}$ bilgi aslında Şam bölgesinin XIII. yüzyıla gelindiğinde ne kadar geniş bir alanı kapsadığını göstermesi açısından önemlidir.

Çalışmamızın da kaynağını oluşturan, dönemin seyyahlarının verdiği bilgilere baktığımızda ise Suriye ${ }^{4}$ den geçen seyyahlar, yolların özellikleri ile ilgili detaylı bilgiler vermişlerdir. Özellikle bölgenin merkezi şehirlerine (Şam, Halep, Hama, Humus) diğer şehirlerden olan uzaklık, kaç günlük mesafede bulundukları, yolun durumu, yol üzerindeki sıkıntılar, tehlikeler, ya da olumlu gelişmeler detaylı bir şekilde anlatılmıştır. Seyyahlar bir şehirden diğerine gidecek kişilerin işlerini kolaylaştırmak adına, tespit edebildikleri

\footnotetext{
${ }^{2}$ Muhsin D. Yusuf, Economic Survey of Syria During the Tenth and Eleventh Centuries, Klaus Schwarz Verlag, Berlin 1985, s. 80-81.

${ }^{3}$ Ebu'l Fidâ, Takvimü'l-Buldan, Çev. Ramazan Şeşen, Yeditepe Yayınevi, İstanbul 2017, s. $205,230$.

${ }^{4}$ Dönemin Seyyahları Suriye'den bahsederken, “Şam bölgesi, Şam'ın kuzeyi ya da Şam'ın güneyi” şeklinde bölgeyi tarif ediyorlardı. Bölgeye, Şam denilmesinin sebebinin de; Ka'be'nin şamesinde yani sol tarafında kaldığı için bu şekilde adlandırılmasına sebep olduğu tahmin edilmekteydi. Ayrıntılı bilgi için bakınız; Mukaddesî, Ahsenü't-Tekâsîm, Çev. Ahsen Batur, Selenge Yayınları, İstanbul 2015, s. 163.
} 
kestirme yollardan da bahsetmişlerdir. Ayrıca kullanılan bu yolların yüzey şekilleri hakkında da bilgi vermekteydiler ki bu sayede sürüleriyle, ağır yükleriyle geçecek olan tüccarların nasıl bir coğrafi durum ile karşı karşıya kalacaklarını önceden öğrenmelerini sağlamaktaydılar. Suriye bölgesinde genel itibariyle Hac yolları güvenlik açısından diğer yollara nispeten daha güvenli olduğu için tüccarlar bu yolları daha fazla tercih etmekteydiler. Kara yolculuğunda kamu işçileri ulaşım imkânları için çalışır, köprüler inşa ederlerdi. Belirli duraklarda kervansaraylar inşa edilirdi. Kervansaraylar bazı dönemlerde askeri savunma binaları olarak da kullanılmaktaydı. Askeri güvenlik ise Ribatlarla (karakol) sağlanırdı. Ayrıca yol güzergâhında belirli noktalarda yaşayan kabilelerden de yol güvenliği için yardım istenirdi. $\mathrm{Bu}$ kabilelere yolun güvenliği için, yaptıkları hizmet karşılığında ödemeler yapilird1 $1^{5}$.

Suriye'de karayollarının yapısının ülkenin coğrafi yapısına göre şekillendiğini görmekteyiz. Bu bağlamda kuzey-güney yönlü ulaşım, doğubatı yönlü ulaşıma göre daha yoğun ve daha kullanışlıydı. Bu yolları, Karayolu ve Denizyolu şeklinde ikiye ayırmak mümkündür. Denizyolu ticaretinin karayoluna kıyasla daha hızlı gerçekleştiğini görmekteyiz. Ayrıca güvenlik bakımından da karayoluna göre daha güvenliydi. Fakat denizyolunun kullanımı tüccarlar için pek kârlı değildi. Çünkü gemiyle taşınabilecek yük miktarı daha azdır, ayrıca karada pek çok şehir ve kasabadan geçilirken asıl gidilecek şehrin pazarına varmadan, tüccarlar neredeyse ürünlerinin yarısını yolda satmış oluyordu. Denizyolunda ise böyle bir durum söz konusu değildi.

Önemli bir hususu daha belirtmek gerekir ki o da ülkenin posta servisiydi. Posta servisi, dönemin hükümdarına göre oldukça büyük önem arz etmekteydi. Çünkü elçilerin getirip götürdükleri mektuplar ve acil durumlarda getirilen haberler hayati derecede önem arz etmekteydi. Bu sebeple dönemin siyasi güçleri kontrolü ele aldıklarında ilk iş olarak posta teşkilatına ve kullanılan yolun güvenliğine ayrıca önem vermişlerdi. Çalışmada seyyahların verdiği bilgiler doğrultusunda IX-XI. yüzyıllar arasında Suriye bölgesinde hâkimiyet kuran devletlerin kullandıkları yollar ya da kendileri için daha elverişli olabileceğini düşündükleri, yeni yaptırdıkları yolları, tarif edilen bilgiler doğrultusunda harita üzerinde göstermeye çalışılmıştır.

\footnotetext{
${ }^{5}$ Muhsin D. Yusuf, Economic Survey of Syria ..., s. 102.
} 


\section{IX. ve X. yüzyıllarda Suriye'de Yaşanan Hâkimiyet Mücadelelerinde Yolların Durumu}

871-904 yılları arasında Misır'da, bir Türk devleti olan Tolunoğulları hâkimiyet sürüyordu. 883 yılında Abbasi Halifesi Mu'temid döneminde, Muvaffak'in kardeşi Ebu Cafer el-Mu'temid, Misır'a Ahmed b. Tolun'u atamışt1 ${ }^{6}$. Bu dönemde Türklerin izledikleri politika neticesinde Misır bölgesinin zenginliği ve refah seviyesi Bağdat'ı yani Abbasi Devleti'nin zenginliğini geride bırakmıştı. Tolunoğulları'nın hâkimiyet sahası doğal olarak Suriye sınırlarına uzandı ve burada hem Abbasi Devleti ile hem de Bizans ile kaçınılmaz olarak mücadelelerde bulundular. $\mathrm{Bu}$ mücadeleler Tolunoğulları'nın ardından gelen İhşidiler döneminde de yaşandı. Örneğin İhşidi Devleti'nin kurucu Muhammed b. Tuğç, Şam valisi olduğu dönemlerde bölgede büyük bir tecrübe kazandı, hatta Bizans ile yapılan savaşların ardından anlaşmaya varılan esir değişimi maddesini uygulayan kişidir. 946 yılında yaptı̆̆ 1 esir değişimi ile yaklaşık 2482 Müslümanı Bizans'ın elinden kurtarmış oldu ${ }^{7}$. Bu gelişmeler sahip olduğu tecrübeyi göstermesi açısından önemlidir.

Suriye bölgesine Firat Nehri güzergâhı kullanılarak Bağdat ve Basra şehirlerinden gelen kervanlar hiçbir engelle karşılaşmadan Fırat Nehri kıyısını takip ederek Suriye'ye kadar gelebilmekteydiler. Bu güzergâhta iki önemli nokta mevcuttu. Bunlardan biri Rakka diğeri ise Balis'ti. Öyle ki Araplar Balis şehrine "Suriyelilerin limanı" demekteydiler". X. yüzyılda

Suriye bölgesine gelen Mukaddesî, buradaki kervansarayların bakımlı ve göz alıcı nitelikte olduğunu vurgularken güçlü sınır karakollarına sahip olduğunu da belirtmekteydi. Remle şehri için ekmeğinin beyaz olduğunu, Humus ve Taberiye'de fiyatların düşük havasının çok güzel, üzüm bağlarının ve mahsullerinin bol olduğunu vurgulamıştır. Ayrıca ülkede mermer yatakları ve ilaç üretiminde nebatatın da bol olduğundan bahsetmiştir ${ }^{9}$. Pazarlarında çeşit fazlalığı söz konusudur, tacirler, zanaatkârlar ve tabipleri fazla bir ülkeydi. Ancak bu dönemde kuzeyden gelen Bizans saldırılarından dolayı sınır şehirlerinin iç kesimlere göre çok kötü bir halde olduğunu da vurgulamak gerekmektedir. Hamdanî hâkimiyetindeki Kuzey Suriye'de çatışmalar daha çok bu sınır şehirlerinde yaşanmaktaydı.

\footnotetext{
${ }^{6}$ Şükrullah Efendi, Behcetü't-Tevârîh, Çev. Hasan Almaz, Mostar Yayınevi, İstanbul 2013, s. 357.

${ }^{7}$ Mesûdî, Kitâbü't-Tenbih ve'l-İşraf, Çev. Ramazan Şeşen, Bilge Kültür Sanat, İstanbul 2018, s. 142-260, 263.

${ }^{8}$ Heyd W, Yakındoğu Ticaret Tarihi, Çev. Enver Ziya Karal, TTK, Ankara 2000, s. 49

${ }^{9}$ Mukaddesî, Ahsenü't-Tekâsîm, s. 160, 162.
} 
Mukaddesî Suriye'yi altı bölgeye ayırmaktaydı, bunlar; Kınnesrin, Humus, Dımaşk, Ürdün, Filistin ve Şerat şehirleriydi. Kınnesrin bölgesinin merkez şehri Halep'ti. Mukaddesî, Humus'tan bahsederken burada pazar olduğundan ve fiyatlarının düşük olduğundan bahsetmiştir ${ }^{10}$. Bu durum bölgenin tüccarlar açasından çok fazla ziyaret edildiğini göstermektedir. Daha sonra bu altı bölgenin sınırları içerisinde bulunan şehirlerin isimlerini tek tek saymıştır ${ }^{11}$. Suriye bölgesinde X. yüzyılın ikinci yarısında ticari faaliyetler çok yüksek ve oldukça kârlıydı. İthal ve ihraç ürünler çok fazla ve çok çeşitliydi. Ayrıca vergiler de ağır değildi ${ }^{12}$. Bunlar bölge pazarlarına olan ilgiyi arttıran önemli etkenlerdi. Para birimi ve paraların ağırlığı ise aşağı yukarı aynıydı. X. yüzyılda bölgede bulunan bir diğer seyyah ise İbn Havkal'dır. O da Şam (Dımaşk) şehrini merkez şehir ve en büyük şehir olarak ifade ederken, diğer illerde dâhil olmak üzere, şehirlerin fiziki yapıları hakkında bilgi vermekteydi. Şam Suguru ile el-Cezire Suguru arasında bulunan dağlara Rum dağları demektedir. Rum dağları olarak nitelendirilen bu dağların isimlerinin Lukam Dağları olduğu söylenmekte ve 200 fersah uzunluğunda olduğu bahsedilmektedir. Bu dağlar Sugur'ş-Şam ile Sugur el-Cezire bölgelerini birbirlerinden ayıran bir sınır vazifesi görmekteydi. Lazkiye'yi geçtikten sonra dağların Behra ve Tenuh adlarıyla iki kola ayrıldığını ve Şam boyunca bir kolun Kızıldeniz'e diğerinin de Mukattam Dağına kadar uzandığından bahsetmektedir ${ }^{13}$.

964 yılında Bizans saldırıları karşısında Halep Hamdanî hükümdarı Seyfü'd-devle'ye yardım etmek için yaklaşık 5 bin Türkmen Horasan'dan Halep'e doğru yola çıktılar. Güzergâhları; Horasan, Azerbaycan, Ermeniyye, Meyyâfârikîn, Harran ardından Halep idi. Ancak Halep bölgesinde zaten sürekli bir savaş durumu olması, buna ilaveten yaklaşık 5 bin kişinin de bölgeye gelmesi fiyatlarda çok büyük bir artışın yaşanmasına sebep oldu ${ }^{14}$.

966-968 yıllarında Halep Arap kabilelerinden biri olan Hamdanîlerin elinde bulunmaktaydı. Burayı 961-962 yıllarında Mısır'da bir Türk Devleti olan İhşîîlerin elinden ald ${ }^{15}$. Sa'du'd-devle hâkimiyetindeki bölgede Bizans

\footnotetext{
${ }^{10}$ Mukaddesî, Ahsenü't-Tekâsîm, s. 171.

${ }^{11}$ Mukaddesî, Ahsenü't-Tekâsîm, s. 167.

${ }^{12}$ Mukaddesî, Ahsenü't-Tekâsîm, s. 193, 194, 203.

13 İbn Havkal, Sûrat el-Arz, Çev. Ramazan Şeşen, Yeditepe, İstanbul 2017, s. 166-171; İstahri, Mesâliku'l-Memâlik, (Ülkelerin Yolları), Çev. Murat Ağarı, Ayışı̆̆ı Kitapları, İstanbul 2019, s. 60-61.

${ }^{14}$ Miskeveyh, Tecâribü’l- Ümem, Trc. Kivameddin Burslan, TTK, Ankara 2016, s. 593-594; Sibt İbnü'l-Cevzî, Mir 'âtu'z-zamân fi târîhi'l-a yân, Cilt 17, el-Resalah el-A 'lamiah, Beirut 2013, s. 364.

${ }^{15}$ Urfalı Mateos, Mateos Vekayi-Nâmesi(952-1136) ve Papaz Grigor'un Zeyli (1136-1162), Çev. Hrant D. Andreasyan, TTK, Ankara 2000, s. 5.
} 
ile sürekli bir mücadele durumu söz konusuydu. Bu sebepten dolayı AntakyaHalep arasındaki ticari yollar Bizans'ın kontrolü altındaydı. 960-961 yılları Hamdanîlerin Bizans sınırlarına düzenlediği seferlerin sayısının azalmaya başladığı bir dönemdi. II. Nikephorus döneminde (963-969) Suriye bölgesinin birçok şehri Bizans'in elindeydi ve bölgede sürekli bir kargaşa hali söz konusuydu. Ayrıca ekinlerin büyük bir bölümü bu savaş hali nedeniyle harap olmuştu $^{16}$. Bu dönem Halep hükümdarı imzaladığı anlaşma gereği Bizans'a y1llık vergi ödemeyi kabul etti ve Bizans'1n vasalı durumuna düştü ${ }^{17}$. Böylece bölgeden geçecek olan Bizanslı tüccarlarında güvenliğini sağlayacakları yönünde anlaşma yapmış, olası bir zarar durumunda kervanların zararlarını da karşılama adına garanti de vermiş oldu. Bu tahribatın etkisi Dımaşk'a, Efameya'ya (Afamia), hatta Lazkiye'nin $50 \mathrm{~km}$ güneyindeki Banyas'a (Baniyas) kadar ulaştı ${ }^{18} .966$ yılında Benî Süleyman kabilesi Hac yolculuğu için Mekke'ye gitmekte olan Mağrib, Mısır ve Şam kafilesinin yolunu kesip hacılar ve kervanları yağmaladılar ${ }^{19}$. Bu gelişme bölgedeki otorite eksikliğinin en büyük örneklerinden bir tanesini teşkil etmekteydi. 970 yılına gelindiğinde ise Şam, Fatımi Devleti'nin eline geçti. Bu kargaşa ortamından faydalanan Fatımi Devleti Humus'a kadar ilerledi ve burayı da hâkimiyeti altına $a l d 1^{20}$. X. Yüzyılda Suriye bölgesinde yol güvenliği konusunda sivrilen ve adını duyuran Bekcûr et-Türkî adında bir Türk vali idi. Bekcur, Hamdanîler döneminde Humus'a, Fatımiler döneminde ise Şam'a vali olarak atanmıştı. Suriye bölgesinin güvenliği hususunda tam yetkiye sahipti. Hâkimiyeti altındaki hemen hemen her noktada kuleler ya da askeri birlikler yerleştirdi. Böylelikle bölgede huzur ve sükûnet ortamı sağlanmış oldu.

\section{Selçuklu Hâkimiyetindeki Suriye'de Ticari Faaliyetler}

IX. ve X. Yüzyılda Abbasi Devleti'nin bölgeden elde ettiği gelir ortalama 388 milyon 291 bin dirhem civarındaydı. XI. yüzyılda bölgenin kontrolünü elinde bulunduran Selçukluların bu bölgeden elde ettiği gelir ise yaklaşık olarak 210 milyon dinar civarındayd ${ }^{21}$. Dönemin siyasi koşullarını göz önünde bulundurduğumuzda bölgedeki karmaşık yapı ve Bizans baskısı da

\footnotetext{
${ }^{16}$ Scylitzes, J, A Synopsis of Histories, Trns. John Wortley, The Centre of Hellenic Civilization at the University of Manitoba, Canada 2000, s. 202.

${ }^{17}$ Ostrogorsky G, Bizans Devleti Tarihi, 8.Baskı, Çev. Fikret Işı1tan, TTK, Ankara 2015, s. 269-270; A.A.Vasiliev, Bizans Imparatorluğu Tarihi, Çev. Arif Müfid Mansel, Cilt 1, Maarif Yayinevi, Ankara 1943, s. 390-391.

18 Diakanos, L, The History of Leo the Diakanos, Trns. Alice-Mary Talbot and Dennis F. Sullivan, Dumbarton Oaks Trustees for Harvard University, Washington DC 2005, ss. 76, 119, 208-209.

${ }^{19}$ Miskeveyh, Tecâribü'l- Ümem, s. 605.

${ }^{20}$ Çelik A, Fâtımîler Devleti Tarihi (909-1171), TTK, Ankara 2018, s. 188-190.

${ }^{21}$ Tabakoğlu A, Türk İktisat Tarihi, 7. Bask1, Dergâh Yayınevi, İstanbul 2005, s. 80.
} 
hesaba katılınca Türklerin ticaret yollarında sağlamış olduğu güven ortamı, elde ettiği gelir ile kendini açıkça göstermektedir. Bu tüccar kervanları bölgeye, Türkistan, Harizm, İran, Azerbaycan, Irak ve ardından Suriye istikametinde geliyorlard ${ }^{22}$. Selçuklular Şam bölgesini Arap kabilesi olan Mirdâsîlerden almıştı. Mirdâsîler İbn Şebl, Beni Kilab aşiretine mensuplard $1^{23}$. Selçuklulardan hemen önce bölgede hüküm süren Mirdâsî Emirliği Halep bölgesinde Bizans ile 1028-1075 dönemlerinde ciddi mücadelelere girmişti ${ }^{24}$. Nasr b. Salih b. Mirdâs döneminde bölgeye saldırıda bulunan Bizans ordusu büyük bir özgüven ile çıktığı bu seferde Antakya'ya kadar her yeri ele geçirdi. Fakat Romanos, Halep bölgesinde girmiş olduğu mücadelelerden eli boş döndü ${ }^{25}$. Bu mücadeleler neticesinde Bizans'ın Halep bölgesini ele geçirmesini önlemiş oldu. Mirdâsî Emirlerinden Mahmud, 21 Eylül 1075 yılında, 7 yıl boyunca Bizans'in elinde bulunan Menbic'i ele geçirdi ve Bizans'1 buradan da çıkarmayı başard1 ${ }^{26}$. Sultan Alp Arslan ise 1071 y1lında Kahire üzerine sefere çıktığında Halep bölgesine gelmişti. Burada Mirdâsî Emiri, Mahmud el-Mirdâsî hüküm sürmekteydi. Kısa sürede şehri sultana teslim etmekten başka çaresi kalmayan Emir Mahmud, bu tarihten sonra Halep'i artık Büyük Selçuklu Devleti adına yönetmeye başladı.

Selçuklu soyundan olan bir diğer hükümdar, Sultan Melikşah'ın kardeşi Tacü'd-devle Tutuş'tur. O da abisinin emri üzerine Suriye'ye gelip bölgeyi Selçuklu Devleti adına yönetmeye başladı. 1086 yılında bölgedeki karışıklığ kontrol altına almak için bölgeye sefer düzenleme kararı alan Sultan Melikşah'ın Nişabur'dan Halep'e kat ettiği mesafenin toplamda 10 gün olduğu ifade edilmektedir ${ }^{27}$. Melikşah'ın takip ettiği güzergâh ise şu şekildedir; İsfahan'dan çıkıp Musul'a geldi burayı kontrolü altına aldı ${ }^{28}$. Anadolu'ya girdikten sonra Urfa'ya gelip burayı teslim aldı, buradan Caber Kalesine yönelip burayı ele geçirdi ve kaleyi Salim b. Malik b.Bedran elUkayli'ye teslim etti ${ }^{29}$. Ardından Fırat Nehri'ni geçip Suriye'ye giriş yaptı ve burada ilk girdiği şehir Menbiç oldu. Menbiç'in ardından Halep'e girdi.

\footnotetext{
${ }^{22}$ Tabakoğlu A, Türk İktisat Tarihi, s. 126.

${ }^{23}$ Urfalı Mateos, Mateos Vekayi-Nâmesi, s. 53.

${ }^{24}$ Ioannes Zonaras, Tarihlerin Özeti, Çev. Bilge Umar, Arkeoloji ve Sanat Yayınevi, İstanbul 2008, s. 48-50.

${ }^{25}$ Psellos, M, Khronographa, Çev. Işın Demirkent, TTK, Ankara 2014, s. 38.

26 Ahmed b. Mahmud, Selçuknâme, Haz. Erdoğan Merçil, Bilge Kültür Sanat Yayınevi, İstanbul 2011, s. 132.

${ }^{27}$ El-Hüseyni, Ahbârü'd-devleti's-selçukiyye, Çev. Necati Lügal, TTK, Ankara 1999, s. 43-44.

${ }^{28}$ Râvendî, Râhatü's-sudûr ve âyetü's-sürûr, Cilt 1, 2. Baskı, Çev. Ahmed Ateş, TTK, Ankara 1999, s.127.

29 İbnü'l Verdi, Tetimmetü'l-Muhtasar fi Ahbari'l-Beşer, Çev. Mustafa Alican, Kronik Yayınevi, İstanbul 2017, s. 43.
} 
Burayı da Kasımu'd-devle Aksungur'u vali olarak atad ${ }^{30}$. Halep'ten sonra Lazkiye, Kefertab ve Efamiye şehirlerini teslim aldı. Daha sonra bölgeyi kardeşi Tutuş'a bırakıp geri döndü. (Bkz. Ek. 3).

Kasımü'd-devle Aksungur, Büyük Selçuklu Devleti adına bölgede kontrolü eline aldı. Halep bölgesinde çok büyük bir otorite kurdu, güvenliği çok s1k1 tuttu ve bölgeye çok büyük hizmetleri oldu. Kroniklerin tabiriyle, eşkıyaların kökünü kazıdı. Onun zamanında insanlar gece vakti bile rahatça yolculuk yapabiliyordu. Aksungur'un bu çabaları neticesinde Suriye'nin kuzeyinde büyük bir güven ortamı sağlandı. Hatta insanlara zarar veren, kervanlar için tehlike durumunda bulunan çakalları dahi toplatarak yol güvenliği hususunda her adımı atmaktan geri kalmad1 ${ }^{31}$. Güven ortamı beraberinde istikrarı da getirdi. İstikrar, ülkeyi tüccarların uğrak mekânı haline getirdi. Beraberinde Suriye, para akışı ve refah seviyesi yüksek bir ülke konumuna geldi.

Sağlanan bu güven ortamı bölgede çıkarları olan güçlerin işine gelmiyordu. Birbirlerine düşman kabileler kışkırtılarak huzursuzluk ortamı çıkarılıyor ve güven ortamı yok edilmeye çalışılıyordu. Bu devletlerden bir tanesi Fatımi diğer ise Bizans idi. Bu bağlamda 1095 yılında Suriye sahil şehirlerindeki düzeni bozup iç kesimlerdeki istikrarı zedelemeye yönelik faaliyetlerde bulunmaya başlayan Humus valisi İbn Mula'ib bölgede tüccar kervanlarına saldırılar düzenlemeye başladı. Bu gelişmeler üzerine Selçuklu Devleti bölgeye ordu sevk ederek kontrolü yeniden ele aldı. İbn Mula'ib ise Mısır'a, Fatımi Halifesinin yanına kaçmayı başardı. Fakat pes etmedi ve bir y1l sonra Efameya'ya (Afamia) geçerek istikrarı bozacak faaliyetlerine yeniden başladı. Genel itibariyle çok ciddi bir savaşın eşiğine gelinmemişse bölgede kontrol kimde olursa olsun ticaretin aksamaması için gerekli hassasiyet gösteriliyordu. Düşman ülkelerin tüccarları alış-verişe devam ediyorlardı. Eşkıyalar ve bedeviler bu koşulun dışında kalan kesimdir. Onlar için siyasi durumun bir önemi yoktu, firsatını buldukları anda kervanlara saldırmaktan çekinmiyorlardı. Burada siyasi otoriteye düşen görev, bölge kabilelerine bir miktar ödeme yaparak, ticaret güzergâhında meydana gelebilecek eşkıyalık faaliyetlerinin önüne geçmekti.

Arap kabileleri devletlerden aldıkları para ile güvenliği sağlıyorlardı. Fakat devletin yaptığı bu ödeme aksarsa ya da miktarı yeterli bulmazlarsa güvenlik faaliyetlerine son veriyorlardı 1093 yılında Mekke valisi gerekli ödemeyi

\footnotetext{
${ }^{30}$ Zahîrud'dîn Nîşâbûrî, Selçuknâme, Çev. Ayşegül Fidan, Kopernik Yayınevi, İstanbul 2018), s. 94; Urfalı Mateos, Mateos Vekayi-Nâmesi, s. 171-172.

31 İbnü'l Adîm, Zübdetü 'l-Haleb min Târîhi Haleb (1055-1127), Çev. Ali Sevim, TTK, Ankara 2014, s. 65.
} 
yapmadığı için Suriye ve Mısır hacılarının mallarına saldırıldı. Bu güvenlik sorunu yüzünden bu yıl hacilar hac görevlerini yerine getiremediler. Bedevilerin bu faaliyetleri IX. ve X. yüzyılda gerçekleşti ${ }^{32}$. Bu bölgedeki büyük kabileler, siyasi otoritelere sürekli isyan etti. Bedevilerden oluşan Karmati kuvvetleri de ülkeyi felakete sürükledi. Bedeviler saldırı aldıklarında da sürekli çöllere çekilip kaçıyorlardı. Yol boyunca kervanlara saldırılar düzenleyen bedeviler önemli su kaynaklarını da kullanılamaz hale getiriyorlardı. Özellikle çöl yollarındaki güven ortamı tamamen kayboldu. Bunların dağlık arazilerde pusu kurarak saldıranlarına "cebeliler" yani dağl1lar denilmekteydi. Suriye-Irak bölgesinde yol kesen eşkıyalara "Nuheyda", ya da yaptıkları kötü davranış ve hırsızlıklardan dolayı "Harâmî" denilmekteydi ${ }^{33}$. Bölgenin en büyük çöllerinden biri olan Samawah (Samava) Çölü'nden 12 tane ana yolun geçtiği söylenmekteydi. Bunların 9 tanesi Hac yolu olarak kullanılıyordu. Bunlardan biri Mısır, beşi Suriye, üçü Iraktan geçiyordu ${ }^{34}$. Yine Medine'nin kuzeyinden Misır'a giden önemli bir yol daha vardı. Bu yollar çok büyük öneme sahip yollardı. Çöller eşkıya bakımından çok fazla tehlike arz etmiyordu. Fakat çöllerin tehlikesi daha çok doğal ortamından kaynaklıydı. Hava sıcaklığı, kum firtınası, çöl yılanları, bit çeşitleri ve kaybolma tehlikesi gibi ${ }^{35}$. Çölde yolculuk yapanlar büyük bir olasılıkla, yolculuk esnasında bir sebepten dolayı yaşamını yitirmiş cesetlerle, iskeletlerle karşılaşırdı.

1095 yılında Suriye Selçuklu Meliği olan Tutuş’un vefatının ardından ise yerine Suriye'de bıraktığı iki oğlu Rıdvan ve Dukak aralarında anlaşamayarak bölgeyi ikiye bölüp yönetmeye başladılar. Rıdvan Halep bölgesini yönetimi altına alırken Dukak'ta Şam'a yerleşti. Bu dönem Haçlıların Suriye'ye geldikleri dönemdi ${ }^{36}$. Haçlı istilalarının yaşandığ 1 bu dönem Suriye ekonomisinin neredeyse yüz yıl boyunca gerileme yaşadığı dönem olarak kayda geçmiştir. Haçlılar bölgeye geldiklerinde ticari yolların güzergâhları ya değiştirilmek zorunda kalındı ya da kapand1. Ancak zamanla Haçlılar ticaretin korsanlıktan daha fazla getirisi olduğunu fark ettikten sonra onlarda bu ticari akışın bir parçası olmak için girişimlerde bulunmaya başladılar ${ }^{37}$. Selçukluların Suriye'deki hâkimiyetleri ise 1117 yılında tamamen son buldu.

\footnotetext{
${ }^{32}$ Muhsin D. Yusuf, Economic Survey of Syria, s. 103-104.

33 Özdal A. N, Ortaçă̆ Ekonomisi ve Müslüman Tüccarlar (X.-XIV. Yüzyıllar), Selenge Yayınevi, İstanbul 2016, s. 230.

${ }^{34}$ Muhsin D. Yusuf, Economic Survey of Syria, s. 105.

35 Özdal A. N, Ortaçağ Ekonomisi, s. 221.

${ }^{36}$ Müneccimbaşı Ahmed b. Lütfullah, Câmiu'd-düvel, Çev. Ali Öngül, Kabalcı Yayınevi, İstanbul 2017, s. 77, 86, 92; İbnü'l Verdi, Tetimmetü'l-Muhtasar fi Ahbari'l-Beşer, s. 50-51.

37 Özdal A. N, Ortaçă̆ Ekonomisi, s. 231.
} 
$\mathrm{Bu}$ süre boyunca Haçlıları sahil şeridine sıkıştıran Selçuklular, Haçlıların Suriye'nin iç kesimlerine yerleşmelerini engellemiş oldu.

\section{Suriye'deki Ana Yollar ve Ara Yollar}

Suriye içerisinde yolculuk yapan kervanların rotaları genelde Şam ve Halep merkezli olmaktaydı. Zaten yolların hemen hemen hepsi bu iki merkezi şehre çıkıyordu. Fakat takip edilen güzergâhlarda özellikle dönemlere göre farklılıklar oluyordu. S1k sık el değiştiren bir bölgede yolların güvenliği de yolculuk için önemli olduğundan daha güvenli yollar her zaman ilk tercih edilen yollardı. Güvenliğin ardından dikkat edilen ikinci hususta genellikle hangi yolun daha kısa mesafeli olduğuydu. İbn Hurdazbih bu dönemde Halep'e gitmek için en elverişli olduğunu düşündüğü ve kendisinin de kullandığı güzergâhı; Rakka, Balis daha sonra Fırat Nehri'ni boydan boya geçip Huşaf'a geçmek, ardından Nurâ'ya ve buradan da Halep'e geçmekti ${ }^{38}$, şeklinde tarif etmekteydi. İbn Battuta'nın takip ettiği güzergâh ise; Maarratü'n-Nu'mân, Sermin, Halep, Kınnesrin, Tizin ve buradan Antakya, şeklindeydi. Bu bölgelerde üretilen zeytin, meyve, sabun Mısır'a ihraç ediliyordu ${ }^{39}$.

Selçukluların bölgede en çok gelir elde ettiği iktisadi faaliyet, transit ticaretti. Transit ticarette çok ciddi bir kervan akışı mevcuttu ve bu ticari faaliyetler sürekli aktif ve canlıydı. Bu da sürekli hale gelen vergi geliri demekti. Suriye bölgesine Anadolu'dan gelen kervanların güzergâhları ise şu şekildeydi; İstanbul, İzmit, İznik, Eskişehir, Akşehir, Konya, Ulukışla, Adana, Halep, Şam. Halep bölgesinde ise yollar pek çok kola ayrılmaktaydı. Bunlardan bir tanesi ise şöyleydi; Halep, Kilis, Nusaybin, Musul, Bağdat ve Basra güzergâh $1^{40}$. X. yüzyılda Şam bölgesi parçalanmış bir yapıya sahipti bu süreç Selçuklularla nispeten toparlandıysa da Haçlıların bölgeye gelmesinin ardından yeniden kargaşa ortamı hâkim oldu. Fatımiler, Haçlılar bölgeye gelmeden hemen önce el-Efdal, Emirü'l-Cuyüş komutası altındaki Fatımi ordusunu Şam bölgesine gönderdi. Böylelikle Artukluların hâkimiyetindeki Kudüs'ü ele geçirdiler (1097). Bu tarihlerde Lazkiye'den Kahire'ye kadar olan yerler Misır Fatımi Devleti'nin eline geçti ${ }^{41}$. Haçlılarda bölgede

\footnotetext{
38 İbn Hurdazbih, el-Mesâlik ve'l-Memâlik, Yollar ve Ülkeler Kitabı, Çev. Murat Ağarı, Kitabevi Yayınevi, İstanbul 2008, s. 69.

39 İbn Battuta, Tuhfetü'n-Nuzzâr fi Garâibi'l-Emsâr ve Acâibi'l-Esfâr, Cilt 1, Çev. A.Sait Aykut, YKY, İstanbul 2004, s. 103-105-114.

${ }^{40}$ Tabakoğlu A, Türk İktisat Tarihi, s. 128.

${ }^{41}$ Willermus T, Historia rerum in partibus transmarinis gestarum, Çev. Ergin Ayan, Ötüken Yayınevi, İstanbul 2016, s. 168-189.
} 
Antakya'dan sonra Maarratü'n-numan'a ${ }^{42}$ geldiler. Ardından Dârü'lMaarre'ye buradan sonra Kefertab'a sonra Kudüs'e doğru yürüyüşe devam ettiler ${ }^{43}$. Haçlılar 1 Mart 1098 yılında Lazkiye'yi aldılar. Buraya "La Rich" ismini verdiler. Bu dönemde bölgede Bizans'a ait olan tek şehir Lazkiye'ydi. Bizans kontrolündeki bu liman şehir de ele geçirildikten sonra Fatımi kontrolündeki Cebele şehrine girdiler. Şehri Fatımiler adına Vali İbn Süleyha koruyordu. Kuşatma kısa sürede sonuç vermeyince Haçlılar daha fazla zaman kaybetmemek için kuşatmayı kaldırıp yollarına devam ettiler ${ }^{44}$. İşgal sahil şeridinden devam etti.

Şam bölgesinde ana yolların dışında kullanılan pek çok ara yol vardı. $\mathrm{Bu}$ yollar mesafeyi kısaltma açısından önemliydi. Örneğin; Humus ile Tiberias'1 (Tiberya) Şam'dan geçmeye gerek kalmadan birleştiren ara yollar gibi. Geçilen şehirler; Baa'labek, Ayn al-Jarr, al-Qar'un, al-Uyun, Jab-Yusuf ve Tiberias'tır. Kuzeyden güneye doğru birbirini bağlayan bir diğer kestirme yol ise Rakka ile Humus'u Firat Nehri üzerinden birbirine bağlayan yoldur. Bu yolun önemi büyüktür çünkü Irak'tan Şam'a gidenler için kestirme bir yol niteliğindeydi. Bu yol ile; al-Rusafah, al-Zarra'ah, al-Qastal, Salamiyah şehirlerinden geçilip Humus'a varılırdı. Şam'ın kuzeyinden geçen önemli bir diğer yol ise; Rakka'nın doğusundan başlar, Balis, Halep, al-Atharib ve Antakya içlerine kadar giderdi. Burada yol ikiye ayrıldı. Biri İskenderun kuzeyine diğeri de Lazkiye'nin güneyine gitmekteydi. Şam bölgesinin güneyinde de önemli şehirler vardı. Bunlardan bir tanesi Remle (Ramla) idi. Remle denize pek çok yol ile bağlanmaktaydı. Bunlar; Cesarea, Arsuf, Jaffa (Yafa) ve Askalan şehirleriydi. Fakat ana yol için Azdud ve Rafah şehirlerinden geçilmeliydi. Remle'den doğuya, çöllere giden bir anayol da mevcuttu. Bu yol Kudüs'ten başlıyor Amman'da son buluyordu ${ }^{45}$.

\section{Suriye'den Geçen Hac Yolu Güzergâhı}

Şam bölgesi yolları hem Müslüman hem de Hıristiyan dünyası için kuşkusuz büyük bir öneme sahipti. Bu dönemde Suriye bölgesinde haciların kervan yolları denizden uzak, iç kesimlerden geçiyordu. İzledikleri Hac yolu istikameti Ürdün'ün doğusu ve Filistin'in dışı idi. Bu dönemde, her sene 15 Eylül'de Kudüs'te hemen hemen her millet tarafından ziyaret edilen büyük bir

\footnotetext{
${ }^{42}$ Peygamberimizin yakın arkadaşlarından Nu'mân b. Beşir Ensârî Humus'ta emirlik yaparken bir oğlunu kaybetti. Onu Maarra'ya gömdüler. Bu yüzden bu şehre Maarratü’n-Nu'mân adı verildi ve bu şekilde anılmaya başladı. Ayrıntılı bilgi için bakınız; İbn Battuta, "Tuhfetü'nNuzzâr fi Garâibi'l-Emsâr ve Acâibi'l-Esfâr", s. 102.

43 İbn Kalânisi, Zeyl Tarih-i Dımaşk, Çev. Onur Özatağ, Türkiye İş Bankası Kültür Yayınları, İstanbul 2015, s. 3, 5.

${ }^{44}$ Willermus T, Historia rerum in partibus transmarinis gestarum, s. 302,305.

${ }^{45}$ Muhsin D. Yusuf, Economic Survey of Syria, s. 82-83.
} 
Pazar kurulurdu. Bu pazar bölgenin ciddi bir ekonomik gelir elde etmesini sağlıyordu. Suriye bölgesinde neredeyse tüm ticari yolların kesiştiği merkez şehir Şam'd1. Ülkenin kuzeyinden gelen Hacı kafilesi de Şam'da bir araya gelip buradan birlikte çıkıp Mekke'ye doğru birlikte harekete geçiyorlardı ${ }^{46}$. Bu durum Şam'da ciddi bir para akışına ve ürün çeşitliliğine neden oldu. Bu gelişme ise tüccarları Şam'a çekiyordu. Avrupa'daki Hıristiyan hacılar denizyoluyla gelmektense İtalya'dan İstanbul'a denizyoluyla geçip buradan yolculuklarına karayoluyla devam ediyorlardı. Böylelikle yolculuğun daha az maliyetli ve daha ucuz hale geldiği söylenmekteydiler ${ }^{47}$.

Transit ticaret yollarının yanında Hac yollarının da aynı güzergâhtan geçmesi bu yolların önemini daha da arttırmaktaydı. Hac yolculuğuna çıkan hacılar Şam bölgesinde genelde Dımaşk'ta (Şam) bir araya gelip buradan Mekke'ye doğru harekete geçiyorlardı. Bu yolculukta şu şehirleri takip ediliyordu; Yemame'den Urz'a sonra Hadika'ya, sonra Seyh'a ardından Eksibeti'l-Akar'a sonra Şakirâ'ya sonra Sedd'e sonra Sidara'ya, Suveyka'ya buradan Basra yolu üzerindeki Karyateyn'e (Al Quaryatayn) varılıyordu ${ }^{48}$. Tarif edilen bir diğer Hac yolu ise şu şekildedir; Şam, al-Kuswah, alSanamayn, Adri'at, al-Zarga, Amman ve Ma'an Tabuk, al-Madinah şehirleri kullanılmaktaydı.(Bkz. Ek. 4). Mısır ve Kuzey Afrika hacılarının kullandığı hac yolu ise daha çok Şam bölgesinin içine girilmeden ülkenin köşesinden geçen yoldu. Bu yol ile al-Quizum'dan başlar Sinai Çölü geçilir ve ardından Aylah'a varılırdı. Buradan güneye sahil yoluna dönüldükten sonra Yanbu şehrinden geçilirdi. Buradan da Mekke ve Medine'ye varılırdı. Sayılan bu şehir isimleri Arap seyyahlar arasında farklılık gösterebilmekteydi. Her seyyah kendi dönemine göre telaffuz edilen şehir isimlerini kullanmıştır. Şam bölgesinin kesişim noktası olan bu büyük şehirlere komşu ülkelerden bağlanan çok önemli yollar bulunmaktaydı. Bunlar içerisinde öne çıkan Bağdat'1 Şam'a bağlayan ana yoldur. Bu yol Bağdat'tan başlayıp Fırat Nehrini paralel geçip, Rahbah'a gelip buradan da Rakka'ya giden yoldur ${ }^{49}$. Rakka'dan da bilinen güzergâhta Şam bölgesine varılmaktaydı. Bu yollar tahmin edileceği gibi kuzey-güney yönlü yollardır. Bunların dışında sahil şehirleri ile iç kesimleri birbirine bağlayan doğu-batı yönlü yollarda mevcuttu. Ülkenin güneyinden girilip kuzeyine doğru yolculuk yapan, yani Şam'a doğru yolculuk yapan biri hangi şehirlerden geçmiştir diye baktığımızda buna Halid bin Velid'in Şam'ı fethi için izlediği güzergâhı gösterebiliriz. Halid bin Velid

\footnotetext{
${ }^{46}$ Heyd W, Yakındoğu Ticaret Tarihi, s. 47-48.

${ }^{47}$ Muhsin D. Yusuf, Economic Survey of Syria, s. 90-91.

${ }^{48}$ Kudâme İbn Cafer, Kitabü'l Harac, Çev. Ramazan Şeşen, Yeditepe Yayınevi, İstanbul 2018, s. 168.

${ }^{49}$ Muhsin D. Yusuf, Economic Survey of Syria, s. 82, 85.
} 
Şam'a kadar şu şehirlerden geçmiştir; Aynu't-Temr, Sandavdâ, Kurakır, Süvâ, el-Behrâ, el-Kevâsil, Karkısiya, Ereke, Dumetu'l Cendel, Kusam, Tedmür, el-Karyefeyn, Sinnır, Huvvârîn, Mercu Rahıt ${ }^{50}$, yoluyla Şam bölgesine gelmişti. Özellikle belirtmemiz gerekiyor ki bu dönemlerde Şam bölgesinde yol sayısı oldukça fazlaydı. Köyleri, kasabaları birbirlerine bağlayan yollar oldukça fazlaydı. Bu saydıklarımız ise en tanınmış ve en önemli olanlarıydı. Hac yolları olarak bahsedilen bu yollar yalnızca hacıların kullandıkları yollar değil ayrıca önemli birer ticaret yolları olarak da kullanılmaktaydi.

\section{Yüzyılda Saldırılar ve İşgaller Altında Yolların Durumu}

XI. yüzyılda Suriye bölgesinde Tebriz-Halep yolu oldukça işlek bir haldeydi. Nasr-1 Hüsrev'in izlediği güzergâha göre Tebriz'den Suriye bölgesine Suruç şehrinden giriş yapıyordu. Suruç'tan Menbiç'in kuzeydoğusunda, Roma döneminde Kasilina adıyla tanınan, Nacm Kalesi bulunmaktaydı. Bu kale Suriye bölgesi sinır kalelerinden bir tanesiydi. Menbiç’te bulunan köprü aracılığıyla Fırat Nehri'nden karşıya geçip Halep'e gidilirdi. Halep bölgenin ortak pazarı konumundaydı tüccarlar, esnaflar, ürünlerini satmak isteyen herkes Halep'in pazarına gelirdi ${ }^{51}$. XI. Yüzyılın ilk çeyreğinde Şam bölgesinde hâkimiyet kurmuş olan Bizans'ın bu üstünlügü İmparator II. Basil'in ölümünün ardından yerini Araplara bırakmıştı. II. Basil Mısır Halifesi el-Hâkim ile yaptığı anlaşmanın ardından bölgedeki savaş ortamı durulmaya başlamıştı. 1025 yılından sonra bölge kontrolü ağırlıklı olarak Arap emirliklerin kontrolüne geçti. Bu tarihten sonra Halep yeniden Bizans'ın elinden çıktı ${ }^{52}$. XI. Yüzyılın ikinci yarısında bölgeye Haçlılar gelip buralara yerleştiler. Dolayısıyla pek çok liman kent ve önemli yollar Müslümanların elinden çıkıp Hıristiyanların kontrolü altına girdi ${ }^{53}$. Bu gelişme Suriye'nin bütün düzenini bozduğu gibi istikrarın da yok olmasına sebebiyet verdi. Ayrıca liman şehirlerinin kontrolü Haçlılara girince Avrupa'dan gelen-giden malların vergileri de Haçlılara ödenmeye başlandı. $\mathrm{Bu}$ gelişme Haçlıların bölgede tutunmasını sağlayan ekonomik gücün kaynağını oluşturdu. Denizlerden gelen askeri yardımda Haçlıların bölgede tutunabilmelerini sağlayan bir diğer önemli etkendi.

$\mathrm{Bu}$ dönemde Halep ile Şam arasındaki yollar oldukça işlekti. Bu yollar ticari akışın atar damarı vazifesini görürken, Hama ve Humus gibi önemli

\footnotetext{
${ }^{50}$ Belazurî, Fütûhu'l Buldân, Trc. Mustafa Fayda, Siyer Yayınevi, İstanbul 2013, s. 130, 132.

${ }^{51}$ Nasr-1 Hüsrev, Sefernâme, 2. Baskı, Çev. Abdülvehap Tarzi, MEB, İstanbul 1967, s. 31.

52 A.A.Vasiliev, Bizans Imparatorluğu Tarihi, s. 394-395.

${ }^{53}$ Fulcherius Carnotensis, Gesta Francorum Iherusalem Pregrinantium, Çev. İlcan Bihter Barlas, IQ Kültür Sanat Yayınevi, İstanbul 2009, s. 96.
} 
şehirlerinde kervan yolları bu şehirlere bu yollar aracıllğıyla bağlanıyordu. Humus'ta bulunan pazarlara gelen mal akışı da farklı yollardan gerçekleştirilirdi. Çünkü bu yol Humus ile Rakka'yı direkt olarak birbirine bağlamaktaydı. Humus'u bu dönemde İbn Mülaîb adında bir emir yönetiyordu. Fakat İbn Mülaîb'in Mısır Fatımi Halifesi adına sikke kestirmesi bölgede bulunan Selçuklu Meliki Tutuş ve Emir Aksungur'un tepkisine yol açtı. $\mathrm{Bu}$ duruma müsaade etmeyen Tutuş ve Aksungur Humus üzerine yürüyünce İbn Mülaîb Humus'u onlara bırakıp Mısır'a kaçtı. Böylelikle Humus'ta 1090 yılı itibariyle Selçukluların kontrolü altına girmiş oldu ${ }^{54}$. Suriye bölgesinden geçen önemli nehir olan Asi Nehri'nin kuzeyinden gelen Pazar ürünleri güneyde limanlara getirilirdi, bu limanlar bu dönemde Haçlıların kontrolü altındaydı ve sevkiyat Haçlılar tarafından gerçekleştiriliyordu ${ }^{55}$. Görüldüğü üzere devletlerin bölgedeki varllğı büyük oranda iktisadî ve askerî açıdan önemli olan yolların kontrolünü ellerinde bulundurmalarına bağlıydı.

\section{Denizyolu Taşımacılığı ve Ticaret}

Suriye, Doğu Akdeniz'e kıyısı olan ve çok önemli liman kentlere sahip bir ülkedir. Avrupa ve Kuzey Afrika'yı Ortadoğu'ya bağlayan özelliği bölgede emelleri olan devletlerinde iştahını kabartan bir etken olmuştu. Burada hâkimiyet kuran devletlerde bu liman kentlerden oldukça fazla istifade etmişlerdi. Ortaçağ' da Suriye'ye bağlı olarak görülen liman kentleri arasında; Tripoli (Trablus), Tyre (Sur), Acre (Akka), Asqalan (Aşkelon-Ashqelon) ve Lazkiye, Suwayda, Jabalah, Jubayl, Beirut, Sidon, Haifa, Caesarea (Kayserya), Jaffa (Yafa) ve Gazze şehirlerini sayabiliriz. Bunlar Şam bölgesine bağlı liman kentler olarak tarif edilmekteydiler. Özellikle Venedikliler bu limanlar aracılığılla Müslüman ülkelere kereste, demir ve silah ihraç ediyorlardı. Bu ticari akış $X$. yüzyılın ikinci yarısında yoğunluk kazandı. XI. Yüzyılda ise bu ticari akışa Cenevizliler de dâhil oldu. Bu ticari akış bölgenin el değiştirmesinden de çok etkilenmiyordu. Gerek Müslümanlar gerek Bizans gerekse Haçlı kontrolüne giren Suriye limanları bu ticari akıştan olumsuz olarak etkilenmediler. Hatta denizlerde Müslüman ve Hıristiyan tüccarlar birbirlerinin limanlarına, deniz sahalarına girebiliyorlard $1^{56}$. Fakat bu tüccarlar bazen bulundukları ülkenin limanından bilgiler toplayıp, casusluk yapıp bunu geri döndüğünde hükümdarlarına anlatabiliyorlard $1^{57}$. Şam bölgesinde hâkimiyet kurmak bir nevi denizlere de ulaşmak demekti. Bölgede Avrupa ile Ortadoğu'yu birleştiren önemli liman kentler bulunmaktaydı.

\footnotetext{
${ }^{54}$ Ahmed b. Mahmud, Selçuknâme, s. 156-157.

${ }^{55}$ Heyd W, Yakındoğu Ticaret Tarihi, s. 184.

${ }^{56}$ Muhsin D. Yusuf, Economic Survey of Syria, s. 87.

${ }^{57}$ İbn Havkal, Sûrat el-Arz, s. 189.
} 
Selçukluların bu şehirlere hâkim olması Avrupa'dan gelen İtalyan denizcilerin ticari akışlarına zarar vermemiş aksine Doğu Akdeniz'deki ticari faaliyetlerin hızlanmasına vesile olmuşlardı. Özellikle Çin'den ve Hindistan'dan gelen büyük kervanlar ipek ve baharat gibi getirdikleri önemli ticari ürünleri Selçuklu Türkleri ve İtalyan denizciler vasıtasıyla Avrupa'ya aktarıyor ${ }^{58}$ ve bundan her iki tarafta büyük gelir elde ediyordu.

Güneyde Kızıldeniz'e kadar uzanan Suriye sınırı buradan da yapılan ticari faaliyetlerden gelir elde ediyordu. Ancak Kızıldeniz'de yolculuk biraz tehlikeliydi. Kaptanların tecrübeli ve yetenekli olmaları gerekmekteydi. Çünkü Kızıldeniz vadilerin, dağlık alanların mercan kayalıklarının yoğun olduğu bir deniz ve bunların arasından geçmek büyük bir tehlike arz ediyordu. Hatta liman yapıları da gemileri demirlemeye elverişli olmadığı için kaptanlar açıklara demir atıyor, mallar küçük teknelerle kıyıya taşınıyordu ${ }^{59}$. Yolculuk için özellikle gün 1şığından faydalanılmalıydı. Kızıldeniz'de gece yolculuğu çok büyük bir riskti. Tüm bunlara rağmen Kızıldeniz çok tercih ediliyordu. Çünkü Aden Körfezi Müslümanların yoğun olarak kullandığı Pazar bölgelerinden bir tanesiydi ${ }^{60}$. Firat ve Dicle Nehirleri ile başta Bağdat olmak üzere dönemin önemli merkezi şehirlerine deniz taşımacılı̆̆ aracılığı ile ticari akış sağlanıyordu. Bu gemilerle pek çok çeşit gıda ve tekstil ürünleri ayrıca köle taşımacılığı yapılıyordu. Abbasi Halifeleri Bağdat'a kadar uzanan bu deniz taşımacılığından çok istifade etmişlerdi. Akdeniz'de gemilerin salların kıyıyı kaybetmemesi için kıyılara gözetleme kuleleri yaptırılırdı. Bu kuleler hem yön bakımından önemliydi hem de birer gümrük vergisi ödeme noktaları olarak da kullanılmaktayd ${ }^{61}$.

Yakındoğu ile Akdeniz ülkelerini birbirine bağlayan iki rota bulunmaktaydı. Birincisi Kızıldeniz güzergâhı diğeri ise Fırat Nehri güzergâhıydı. İslamiyet'ten önce Kızıldeniz güzergâhı daha fazla önem taşırken, özellikle Abbasiler döneminde Fırat Nehri daha fazla önemli hale geldi. Ancak Mısır'da Fatımilerin bağımsızlığını ilan etmesinin ardından Kızıldeniz yeniden önem kazanmaya başladı. Bu duruma rağmen Firat'ın öneminde bir azalma meydana gelmedi ${ }^{62}$. Özellikle Bizans ticari faaliyetlerinin Halep bölgesine kayması ve Haçlıların bölgeye gelmesi gibi gelişmeler Fırat Nehri’nin önemini daha da arttırdı. Gemi taşımacılığına

\footnotetext{
${ }^{58}$ Tabakoğlu A, Türk Ikktisat Tarihi, s. 127.

59 Özdal A. N, Ortaçağ Ekonomisi, s. 195.

${ }^{60}$ Muhsin D. Yusuf, Economic Survey of Syria, s. 87-88.

${ }^{61}$ Özdal A. N, Ortaçă̆ Ekonomisi, s. 228.

${ }^{62}$ Muhsin D. Yusuf, Economic Survey of Syria, s. 90.
} 
elverişli bir diğer Nehir ise Asi Nehri’ydi. Ancak diğerlerine göre çok daha az tercih edilmekteydi.

\section{Karayollarına Kıyasla Denizlerdeki Ticari Hayat}

Suriye'de uluslararası deniz taşımacıllğı önemli bir boyuttaydı. Denizyolu karayoluna göre çok daha hızlıydı. Bu durum tüccarları karayolundan çok, denizyolu taşımacılığına yönlendirdi. Ancak denizyolu ticari gemileri yalnızca yaz aylarında sefere çıkıyorlardı. Çoğu zaman yaz aylarında seferi kaçıran karayoluyla gitmeyip bir sonraki yaz sezonunu bekliyordu. Seferler genel olarak yaz aylarında yapılmaktaydı. Bazı sefer güzergâhlarının tarihleri ise belliydi. Örneğin; Mısır ve Suriye'den batıya doğru yapılan seferlerde Nisan-Mayıs aylarında yolculuk yapılıyordu. Batıdan geri dönüş ise AğustosEylül aylarında yapılıyordu. Yine Kuzey Afrika ve İtalya bölgesinden doğuya doğru seferler Haziran-Temmuz aylarında yapılıyor geri dönüş ise EylülEkim aylarında gerçekleşiyordu. Seçilen bu tarihler denizcilik açısından en az riskin olduğu dönemlerdir. Bu risk durumu yalnızca hava durumu için geçerli değil. Pek çok etken vardı. Örneğin, geminin modeli bunlardan bir tanesiydi. Müslümanlar genelde yelkenli ${ }^{63}$ gemi modelini kullanıyorlard $1^{64}$. Bu durum hem avantaj hem de dezavantaj olabiliyordu. Çünkü yolculuk için rüzgârlı günleri beklemek durumunda kalıyorlardı. Avrupa ve Bizans'ta ise daha çok, iki tarafi kürekle çekilen gemiler kullanılıyordu. Böyle bir durumda rüzgârlı bir günü beklemeye gerek yoktu. Fakat rüzgârlı günlerde de yelkenli gemiler daha avantajlı durumdayd.

Her nehrin taşımada kullanılan sal türü kendi yatağına, coğrafyasına uygun şekilde belirlenirdi. Örneğin Dicle Nehri'nde "Kelek" adı verilen sallar kullanılırdı. Bunlar birbirlerine halatlarla bağlanmış kütüklerin yan yana getirilmesinden hazırlanmıştır. Bu kütükler deri ile kaplanıyor, derinin su almaması içinde koyunyününden kaynatılarak hazırlanan bir madde sürülüyordu. $\mathrm{Bu}$ sallar ile 40 tona kadar ağırlık taşınabiliyordu ${ }^{65}$. Nil Nehri'nde ise "Felluka" adı verilen sallar kullanılıyordu. Bu salların her biri ortalama 200 eşek yüküydü. İbn Battuta Nil Nehri'nde aynı anda 3600 fellukanın yüzebildiğinden bahsetmiştir. Bunların her birinin yüklediği yük bakımından birer servet taşıdığını da vurgulamıştır ${ }^{66}$. Özellikle vurgulamamız gerekir ki Ortaçağ boyunca Müslüman dünyasında bulunan icatlar, pusula, yeni yelken türleri açık deniz yolcuları için büyük bir fayda sağlıyordu. Aksi

${ }^{63}$ Dönemin gemi türleri hakkında detaylı bilgi için bakınız; Ahmet N. Özdal, "Ortaçağ Ekonomisi ve Müslüman Tüccarlar (X.-XIV. Yüzylllar)”, Selenge Yayınları, İstanbul 2016, s. 236, 237.

${ }^{64}$ Özdal A. N, Ortaçağ Ekonomisi, s. 92.

65 Özdal A. N, Ortaçağ Ekonomisi, s. 243.

${ }^{66}$ İbn Battuta, “Tuhfetü’n-Nuzzâr fi Garâibi'l-Emsâr ve Acâibi'l-Esfâr”, s. 48. 
halde yolculuklar çok tehlikeli ve zor bir hal alıyordu. Pek çok gemi ya kayboluyor ya da harap oluyordu. Bu da pek çok can ve mal kaybına sebebiyet veriyordu.

$\mathrm{Bu}$ etkenlerin dişında bir de korsan tehlikesi söz konusuydu. Korsanlar koruması yetersiz olan gemi konvoylarına saldırıyorlardı. Fakat saldıran taraf farklı bir dine mensupsa, bu geliş̧me genelde kutsal savaş adı altında, din savaşlarına dönüşüyordu. Bu da gösteriyor ki tek tek gitmektense büyük konvoylar halinde yolculuğa çıkmak daha güvenliydi. Bunun farkında olan tüccarların bir kısmı da bir araya gelip taşıdığı malın büyüklügüne ve değerine göre gerekirse güvenliği için savaş gemisi dahi kiralayabiliyordu ${ }^{67}$. Bu durum kara taşımacılığında da geçerliydi. Kervanın büyüklügüne göre siyasi otoriteden, yol boyunca yaşanabilecek herhangi bir olumsuzluğa karşı askeri güvenlik temin edilirdi. Bunların içerisinde en büyük ve en önemlisi mevsimsel kervanlardı. Bunların sayısı oldukça fazlaydı ve her sene aynı dönemde topluca yola çıkarlard1 ${ }^{68}$. Kara yolculuğunda deve, ya kiralanır ya da satın alınırdı. Yolcu deve kullanmayı bilmiyorsa devenin yanında onu kullanmayı bilen birini de kiralamak zorundaydı. Tüccar için bir deve gerekirken eşyaları için de ayrı bir deveye ihtiyaç duyulurdu ${ }^{69}$. Karalarda olduğu gibi denizlerde de dönemlere göre siyasi güçlerde değişiklik yaşanıyordu. Örneğin X. yüzyılda Bizans'ın denizlerde üstünlüğü görülürken XI. yüzyılda bu üstünlügün Müslümanlara geçtiği görülmektedir.

İbn Havkal X. yüzy1lda Doğu Akdeniz'deki durum için şu ifadeleri kullanmıştır; " Rumlar zamanımızda Şam ve Misır sahillerini devamlı yağmallyorlar, her yerde Müslümanların gemilerine el koyuyorlar, altyorlar, yardım eden yok. Müslümanlara kim imdat edecek?..." ${ }^{\circ}$. Bu ifadesiyle Bizans'ın üstün olduğu dönemlerde denizlerdeki durumu özetlemesi bakımından önemlidir. Bu olumsuz etkenlere rağmen denizyolu oldukça fazla tercih ediliyordu. Çünkü karayoluna göre daha ucuz maliyeti vardı. Karayolunda tüccarlar çok fazla gümrük noktasından geçiyorlardı. Ayrıca işin içinde hem ürünleri taşıyan hayvanların yemleri, hem yolculuk daha uzun süreceği için tüccar için daha fazla yiyecek hem de geçiş noktalarının fazlalığından kaynaklanan gümrük ödemesinin daha fazla olması durumları karayolunu denizyoluna göre çok daha maliyetli bir hale getirmesine sebep oluyordu. Süre bakımından kıyasladığımızda ise Bağdat'tan Kahire'ye yapılan yolculuğun ortalama 51 gün sürdüğü, işin içine deniz yolculuğu dâhil olunca yine İskenderiye'den Bağdat'a ortalama 21 gün sürdüğü

\footnotetext{
${ }^{67}$ Muhsin D. Yusuf, Economic Survey of Syria, s. 93.

${ }^{68}$ Muhsin D. Yusuf, Economic Survey of Syria, s. 100.

69 Özdal A. N, Ortaçağ Ekonomisi, s. 216, 217.

70 İbn Havkal, Sûrat el-Arz, s. 194, 195.
} 
hesaplanmıştır ${ }^{71}$. Bu farkı maliyet boyutuyla da hesaplarsak aradaki farkı daha iyi görebiliriz.

\section{Yollardaki İletişim Yöntemleri}

İletişim, hayati derecede önem arz etmekteydi. Özellikle siyasi otoriteler bu konu üzerine ayrıca yönelmişlerdi. Tüccarlar bile neredeyse her biri kendi posta servisini geliştirdi. Tabii ki devlet eliyle geliştirilen "Barid" posta servisi en gelişmiş olanıydı. Tüccarların çoğu gönderecekleri mektubu tüccar kervanlarından güvendikleri birine verip onun aracıllğıyla mektubu sahibine ulaştırıyorlardı. Bu postalara gönderenin ve alıcının isimleri yazılmaktayd ${ }^{72}$. Günümüzdeki kargo firmalarında çalışan kurye işlevini görüyordu. $\mathrm{Bu}$ kuryelere Suriye bölgesinde genellikle "Kutubi" denilmekteydi. Araplar ise kuryelere "Sahib al-Kutub" demekteydiler" ${ }^{73}$. Bu kuryeler her seferinde yalnızca bir mektup değil pek çok kişinin mektubunu da taşımaktaydılar.

Ortadoğu'da Barid teşkilatına baktı̆̆ımızda İslamiyet'ten önceki dönemlere kadar uzandığını görmekteyiz. Barid sistemi hem posta için hem de istihbarat için kullanılırdı. Bu sistem, bilgileri olabildiğince hızlı bir şekilde iletmek için tasarlanırdı. Çünkü çoğu istihbaratta zaman, hayati derecede öneme sahipti. Hükümdarlar postayı en hızlı ileten postacıya kesenin ağzını sonuna kadar açarak, postacıyı ödüllendiriyordu. Örneğin Büveyhî hükümdarı Muizzüddevle zamanında dönemin en ünlü ve en hızlı iki postacısı olan Fazl ve Mar'uş günde 40 fersahtan daha fazla yol gidebilmekteydiler. Muizzüddevle bu konuya çok önem verdiği için bu iki postacıyı yarıştırma kararı aldı. Postacıların yarışması durumu halk bazında büyük ilgi görüyordu. Postacılar arasında ciddi yarışlar düzenleniyordu. Kimin daha hızlı koştuğu, kimin daha fazla yol kat edebildiği büyük merak konusuydu. Halk ikisinin yarışmasını büyük bir heyecanla bekliyor hatta üzerlerine iddalara tutuşuyorlard1. Bunlardan birinin Sünni diğerinin de Şii olması ise mücadelenin yarattığı heyecan ve rekabeti çok daha fazla arttırmışt ${ }^{74}$. Bu yarışmalar sıklıkla düzenlenirdi. Posta güzergâhında yol boyunca belirli aralıklarla kurulan istasyonlar vardı. Bir istasyondan diğerine gidecek at, deve ve katırlar hazır bulunurdu. Ayrıca bu şekilde hükümet, mektupları taşıyan yetkilileri ajan olarak kullanıyordu. Yol durumu, coğrafyanın son hali, düşmanın tavrı gibi bilgiler bu ajandan öğrenilirdi.

\footnotetext{
${ }^{71}$ Muhsin D. Yusuf, Economic Survey of Syria, s. 95.

72 Özdal A. N, Ortaçağ Ekonomisi, s. 216.

${ }^{73}$ Muhsin D. Yusuf, Economic Survey of Syria, s. 97.

74 İbnü'l-Esîr, el-Kâmil fi 't-târîh, Cilt 10, Çev. Abdülkerim Özaydın, Bahar Yayınları, İstanbul 1991, s. 496.
} 
Suriye'de X. yüzyılda Suriye'yi Irak'a bağlayan en çok bilinen iki önemli posta yolu vardı. Biri Firat Nehri ile paralel ilerlerken diğeri el-Cezire'den geçip Nusaybin'e buradan da Rakka'ya, Rakka'dan el-Naqirah, Menbiç, Halep, Kınnesrin (Halep'in 28 km güneybatısında Kuveyk Irmağı'nın să̆ yakasında bulunan bir şehirdi ${ }^{75}$. Hama, Humus, Jusiyah, Ba'labek, Şam, Deyr Eyyub, Tiberias (Tiberya), Lajjun, Remle ulaşırdı.(Bkz. Ek. 5). Yol buradan da Mısır'a giderdi. Bir diğer barid yolu; Suriye sınırından geçmekteydi. Halep'i Tarsus ile bağlayan bir yol güzergâhıydı. Halep, Antakya, İskenderun, Misis, Adana, Tarsus şeklindeydi ${ }^{76}$. Kudâme İbn Cafer, Suriye şehirlerinden dönemin önemli posta menzillerini de şu şekilde vermiştir; Menbic'ten Humus'a 1 posta menzili, Kınnesrin'den sonraki Merc bölgesinden Savran'a 7, Humus'a 4, Muhammediye'ye 4, Balabek'e 5, Dımaşk'a 9, Deyr-i Eyyub'a 7 posta menzili bulunmaktayd $1^{77}$.

İletişimde aracı olarak yalnızca insanlar değil güvercin ve duman yöntemleri de kullanılmaktaydı. Güvercin yöntemi daha çok Müslümanlar kullanıyordu. Bu sistem Abbasiler, Fatımiler ve Memlüklüler döneminde sıklıkla kullanıldı. Güvercinler bir şehirden diğer şehre gidecek şekilde eğitilirlerdi. Mektuplarda ayaklarına bağlanırdı. Sultanın güvercinlerinin özellikleri ise yalnızca bir şehir değil pek çok şehre gidecek şekilde eğitilmiş güvercinlerden olmasıydı. Örneğin, 1111 yılında Haçlılar tarafından Sur şehri kuşatma altına alındığı zaman, Sur Emiri İzzülmülk, Dımaşk Atabeyi Tuğtegin'e para gönderip ordusuyla yardıma gelmesini istedi. Tuğtegin'de paranın eline geçtiğini, kuşatma altındaki kaleye haber vermek ve yardıma geleceğini bildirmek için mektubu kaleye sokmak amacıyla güvercin ile yolladi ${ }^{78}$. Bu örnekte gördüğümüz gibi postacı güvercin Şam ile Sur şehirleri arasındaki mesafeyi kat edebilecek kadar eğitilmişti. Bu mesafe çok daha fazla artabilmekteydi. Yine belirli aralıklarla yüksek tepelere gözlem kuleleri inşa edilir ve şehir saldırı alacağı zaman yardım çağırmak amacıyla hızlı bir biçimde haber göndermek için bu kuleler kullanılırdı. Kulelerde ateş yakılır ve dumanı gören bir sonraki kule aynı şekilde bir sonraki kulenin göreceği şekilde duman çıkarırdı. Böylece çok kısa sürede yardım istenen şehre haber verilmiş olunurdu. Bunlar Ortaçağ' da haberleşme ve iletişim adına yapılan ve en çok kullanılan yöntemlerdi.

\footnotetext{
75 Yiğit İ, Kinnesrîn, Cilt 25, DİA, Ankara 2002, s. 419.

${ }^{76}$ Muhsin D. Yusuf, Economic Survey of Syria, s. 98.

${ }^{77}$ Kudâme İbn Cafer, Kitabü'l Harac, s. 180.

78 İbnü'l-Esîr, el-Kâmil fi't-târîh, s. 391.
} 


\section{Sonuç}

Ortaçağ'da Suriye'deki yollara baktığımızda genel itibariyle en önemli anayolların Kuzey-Güney yönlü olduğunu görmekteyiz. Bunda etkili olan faktörlerden biri ülkenin coğrafi durumu, diğeri de merkezi şehirlerin KuzeyGüney yönlü şekilde dizilmiş olmasıydı. Doğu-Batı yönlü anayollar ise daha çok liman kentlere yapılan yolculuklarda kullanılmaktaydı. Ticari hayat ve büyük pazarlar merkezî şehirlerde kuruluyordu. Bu sebeple neredeyse her ara yol bu büyük şehirlere çıkacak şekilde yapılmıştı. Fakat şunu da belirtmek gerekir ki, denizcilik faaliyetlerinin arttığı dönemlerde liman kentlere çıkacak olan yolların önemi daha da arttı. Dönemin seyyahlarının verdiği bilgiler doğrultusunda çizdiğimiz haritalara baktığımızda ticarî, dinî ve askerî yol güzergâhlarının hemen hemen aynı olduğunu görmekteyiz. Genelde tüm ana ve ara yollar Halep ve Şam'a çıkmaktadır. Diğer büyük şehirler dönem dönem önemli hale geldiyse de zamanla yine önemini yitirmiş, isimleri dahi değişmiştir. Fakat Halep ve Şam şehirleri hiçbir zaman önemini yitirmemiştir. Bu sebeple bu coğrafyada hâkimiyet kurabilmek ve bu önemli yollara sahip olabilmek için devletler bu iki şehri ele geçirmek adına kıyasıya bir mücadele içerisine girmişlerdi. Buda Suriye'nin sık sık el değiştirmesine sebebiyet verdi.

Dönemin kroniklerinin anlattıklarına ve yazılmış olan kitabelere baktığımız zaman, bölgenin istikrarının arttığı ve halkın refah seviyesinin yükseldiği dönemin Türklerin kontrolünde olduğu dönem olarak görülmektedir. Selçuklu kontrolünde Suriye, Selçuklu valisi Aksungur yönetimi altında anayollar, tüccarlar ve hacılar için çok güvenliydi. Bu durum ülkeye para akışını ve ekonomik gücü de beraberinde getirdi. Ancak bu istikrar Haçlıların bölgeyi işgaline kadar sürdü. Haçlılar bölgeye geldikten sonra buralara, özellikle liman kentlerine yerleşerek ülkenin bütün düzenini bozdular. Suriye'de anayolların önemini arttıran bir diğer etkende iletişim ve posta servisiydi. İletişism yerli halk için çok önemli bir gereksinimdi fakat hükümdarlar için hayati derecede önem arz etmekteydi. Mesajların, gönderilen haberlerin, olabildiğince hızlı yetişmesi gerekiyordu. Bunun için çok ciddi bir iletişim ağı kurulduğu gibi kullanılacak yollar da itinayla belirlendi. Görüldüğü gibi yollar ve yolların durumu Ortaçağ'da devletlerin ayakta durmalarını sağlayan iskelet vazifesi görmekteydi. 


\section{Kaynakça}

A.A.Vasiliev, Bizans İmparatorluğu Tarihi, Çev. Arif Müfid Mansel, Cilt 1, Maarif Yayınevi, Ankara 1943.

Ahmed b. Mahmud, Selçuknâme, Haz. Erdoğan Merçil, Bilge Kültür Sanat Yayınevi, İstanbul 2011.

Ahmet N. Özdal, "Ortaçağ Ekonomisi ve Müslüman Tüccarlar (X.-XIV. Yüzyıllar)”, Selenge Yayınları, İstanbul 2016.

Belazurî, Fütûhu’l Buldân, Trc. Mustafa Fayda, Siyer Yayınevi, İstanbul 2013.

Çelik A, Fâtımîler Devleti Tarihi (909-1171), TTK, Ankara 2018.

Diakanos, L, The History of Leo the Diakanos, Trns. Alice-Mary Talbot and Dennis F. Sullivan, Dumbarton Oaks Trustees for Harvard University, Washington DC 2005.

Ebu'l Fidâ, Takvimü'l-Buldan, Çev. Ramazan Şeşen, Yeditepe Yayınevi, İstanbul 2017.

El-Hüseyni, Ahbârü'd-devleti’s-selçukiyye, Çev. Necati Lügal, TTK, Ankara 1999.

Fulcherius Carnotensis, Gesta Francorum Iherusalem Pregrinantium, Çev. İlcan Bihter Barlas, IQ Kültür Sanat Yayınevi, İstanbul 2009.

Heyd W, Yakındoğu Ticaret Tarihi, Çev. Enver Ziya Karal, TTK, Ankara 2000.

Ioannes Zonaras, Tarihlerin Özeti, Çev. Bilge Umar, Arkeoloji ve Sanat Yayınevi, İstanbul 2008.

İbn Battuta, Tuhfetü’n-Nuzzâr fi Garâibi'l-Emsâr ve Acâibi'l-Esfâr, Cilt 1, Çev. A.Sait Aykut, YKY, İstanbul 2004.

İbn Havkal, Sûrat el-Arz, Çev. Ramazan Şeşen, Yeditepe, İstanbul 2017.

İbn Hurdazbih, el-Mesâlik ve'l-Memâlik, Yollar ve Ülkeler Kitabı, Çev. Murat Ağarı, Kitabevi Yayınevi, İstanbul 2008.

İbn Kalânisi, Zeyl Tarih-i Dımaşk, Çev. Onur Özatağ, Türkiye İş Bankası Kültür Yayınları, İstanbul 2015.

İbnü’l Adîm, Zübdetü'l-Haleb min Târîhi Haleb (1055-1127), Çev. Ali Sevim, TTK, Ankara 2014. 
İbnü'l Verdi, Tetimmetü'l-Muhtasar fi Ahbari'l-Beşer, Çev. Mustafa Alican, Kronik Yayınevi, İstanbul 2017.

İbnü'l-Esîr, el-Kâmil fí't-târîh, Cilt 10, Çev. Abdülkerim Özaydın, Bahar Yayınları, İstanbul 1991.

İstahri, Mesâliku'l-Memâlik, (Ülkelerin Yolları), Çev. Murat Ağarı, Ayışı̆̆ı Kitapları, İstanbul 2019.

Kudâme İbn Cafer, Kitabü'l Harac, Çev. Ramazan Şeşen, Yeditepe Yayınevi, İstanbul 2018.

Mesûdî, Kitâbü't-Tenbih ve'l-İşraf, Çev. Ramazan Şeşen, Bilge Kültür Sanat, İstanbul 2018.

Miskeveyh, Tecâribü’l- Ümem, Trc. Kıvameddin Burslan, TTK, Ankara 2016.

Muhsin D. Yusuf, Economic Survey of Syria During the Tenth and Eleventh Centuries, Klaus Schwarz Verlag, Berlin 1985.

Mukaddesî, Ahsenü't-Tekâsîm, Çev. Ahsen Batur, Selenge Yayınları, İstanbul 2015.

Müneccimbaşı Ahmed b. Lütfullah, Câmiu'd-düvel, Çev. Ali Öngül, Kabalcı Yayınevi, İstanbul 2017.

Nasr-1 Hüsrev, Sefernâme, 2. Bask1, Çev. Abdülvehap Tarzi, MEB, İstanbul 1967.

Ostrogorsky G, Bizans Devleti Tarihi, 8.Baskı, Çev. Fikret Işıltan, TTK, Ankara 2015.

Özdal A. N, Ortaçağ Ekonomisi ve Müslüman Tüccarlar (X.-XIV. Yüzylllar), Selenge Yayınevi, İstanbul 2016.

Psellos, M, Khronographa, Çev. Işın Demirkent, TTK, Ankara 2014.

Râvendî, Râhatü's-sudûr ve âyetü's-sürûr, Cilt 1, 2. Baskı, Çev. Ahmed Ateş, TTK, Ankara 1999.

Scylitzes, J, A Synopsis of Histories, Trns. John Wortley, The Centre of Hellenic Civilization at the University of Manitoba, Canada 2000.

Sibt İbnü'l-Cevzî, Mir âtu'z-zamân fi târîhi'l-a yân, Cilt 17, el-Resalah el-A 'lamiah, Beirut 2013.

Şükrullah Efendi, Behcetü’t-Tevârîh, Çev. Hasan Almaz, Mostar Yayınevi, İstanbul 2013. 
Tabakoğlu A, Türk İktisat Tarihi, 7. Baskı, Dergâh Yayınevi, İstanbul 2005.

Urfalı Mateos, Mateos Vekayi-Nâmesi(952-1136) ve Papaz Grigor'un Zeyli (11361162), Çev. Hrant D. Andreasyan, TTK, Ankara 2000.

Willermus T, Historia rerum in partibus transmarinis gestarum, Çev. Ergin Ayan, Ötüken Yayınevi, İstanbul 2016.

Yiğit İ, Kınnesrîn, Cilt 25, DİA, Ankara 2002, s. 419-420.

Zahîrud'dîn Nîşâbûrî, Selçuknâme, Çev. Ayşegül Fidan, Kopernik Yayınevi, İstanbul 2018. 


\section{Ekler}

Ek. 1: X. ve XI. Yüzyıllarda Suriye'nin En Çok Kullanılan Anayolu Güzergâhı

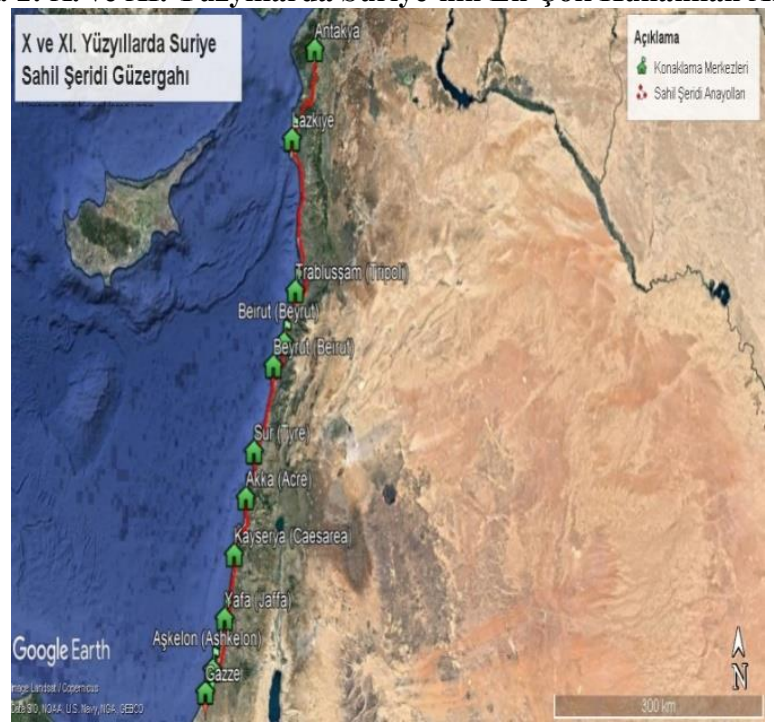

Ek. 2: X. ve XI. Yüzyıllarda Suriye Sahil Şeridi Güzergâhı

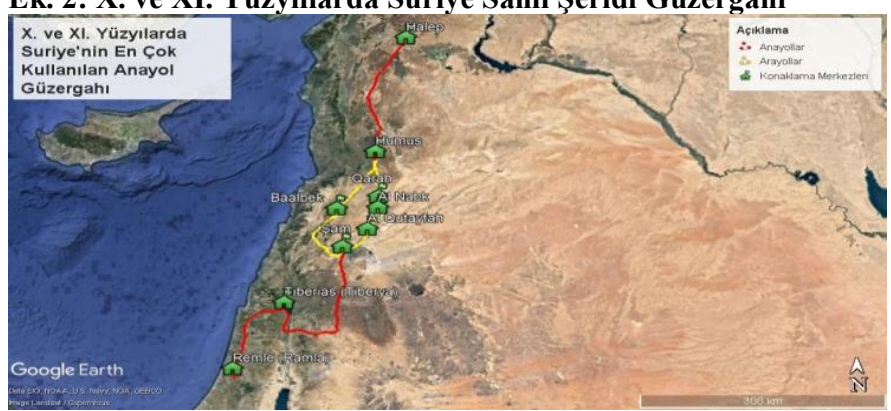


TAD, C.40/S.69, 2021, s.28-54

Ek. 3: Sultan Melikşah'ın Suriye Seferi Güzergâhı (1086)

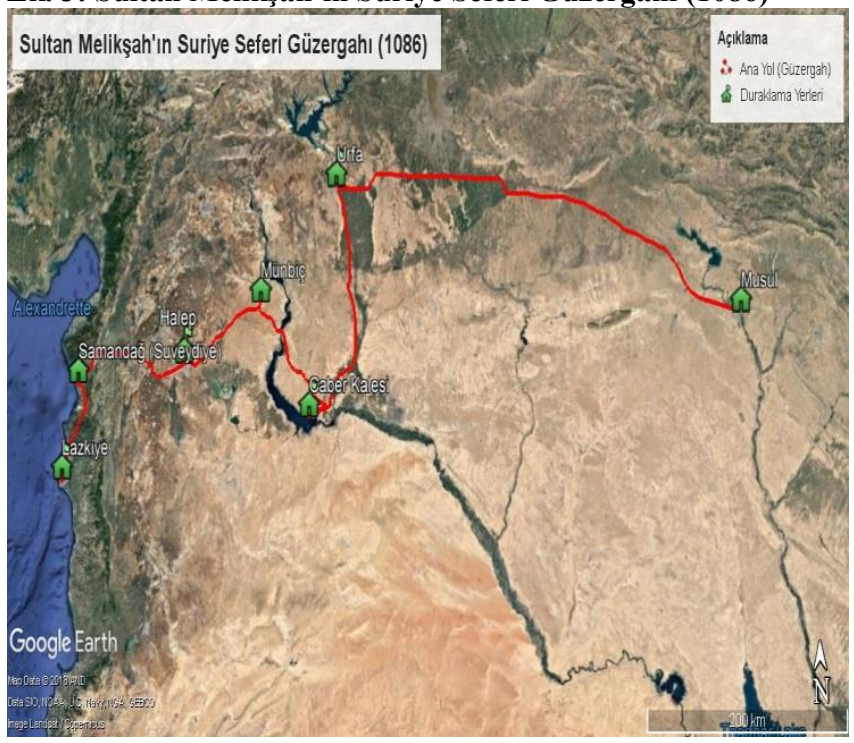

Ek. 4: Hac Yolu ve Transit Ticaret Yolu Güzergâhı

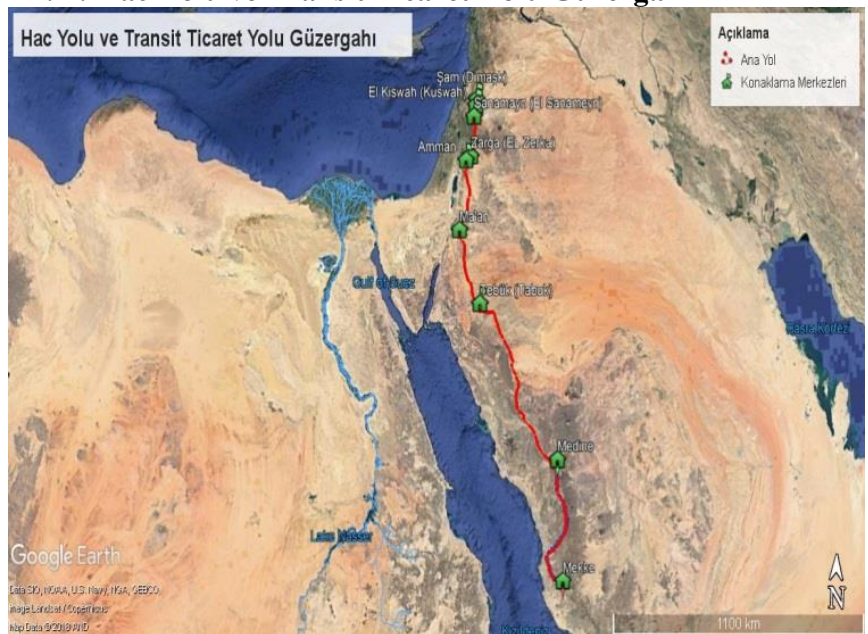


Ek. 5: X. Yüzyıl Posta Yolu Güzergâhı

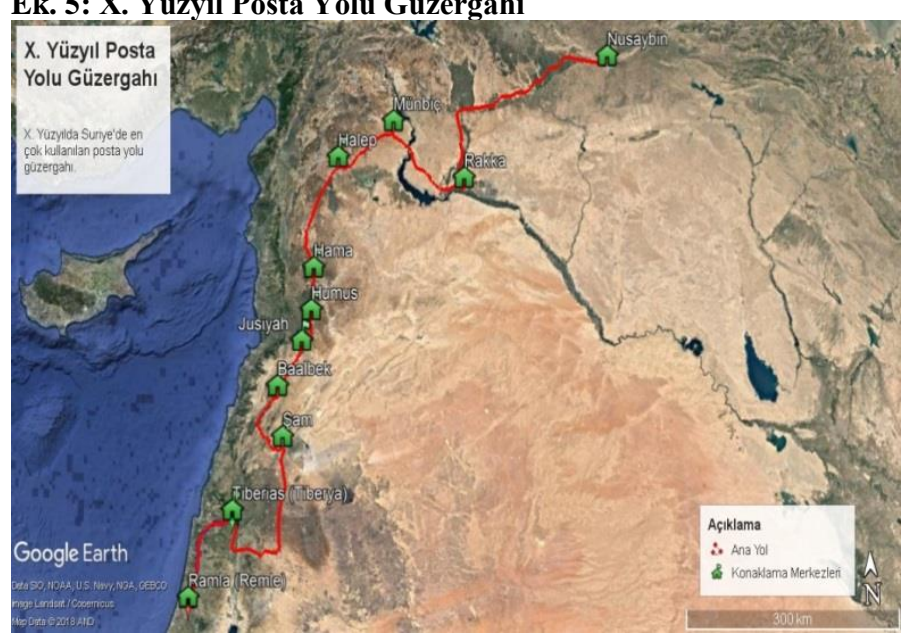

